Article

\title{
Energy Utilization and Environmental Aspects of Rice Processing Industries in Bangladesh
}

\author{
Mohammed Ahiduzzaman ${ }^{1, *}$ and Abul K. M. Sadrul Islam ${ }^{2}$
}

1 Farm Machinery and Postharvest Technology Division, Bangladesh Rice Research Institute, Gazipur-1701, Bangladesh.

2 Department of Mechanical and Chemical Engineering, Islamic University of Technology, Organization of the Islamic Conference (OIC), Board Bazar, Gazipur-1704, Bangladesh; Email: sadrul@iut-dhaka.edu

* Author to whom correspondence should be addressed; E-Mail: ahid72@yahoo.com

Received: 23 November 2008; in revised form: 6 March 2009 / Accepted: 10 March 2009 /

Published: 12 March 2009

\begin{abstract}
In this study, the energy utilization and environmental aspects of the rice processing industries in Bangladesh was analyzed. Rice husk, a milling by-product of rice, is used as a source of thermal energy to produce steam for parboiling of raw rice. The rice is mostly dried on a concrete floor under the sunshine. In mechanical drying, rice husks are used as a source of primary energy. In Bangladesh, the annual estimated energy used in 2000 for the drying of rice by sunshine was 10.7 million GJ and for drying and parboiling by rice husks it was 48.2 million GJ. These amounts will increase to 20.5 and 92.5 million GJ in 2030, respectively. Electrical energy consumption for mechanical drying and milling of rice was calculated as 1.83 million $\mathrm{GJ}_{\mathrm{e}}$ and 3.51 million $\mathrm{GJ}_{\mathrm{e}}$ in 2000 and in 2030, respectively. Biogenic carbon dioxide emission from burning of rice husk is renewed every year by the rice plant. Both the biogenic and non-biogenic carbon dioxide emissions in 2000 were calculated as 5.7 and 0.4 million tonnes, respectively, which will increase to 10.9 and 0.7 million tonnes in 2030. The demand of energy for rice processing increases every year, therefore, energy conservation in rice processing industries would be a viable option to reduce the intensity of energy by increasing the efficiency of rice processing systems which leads to a reduction in emissions and an increased supply of rice husk energy to other sectors as well.
\end{abstract}


Keywords: Rice parboiling, Drying, Rice milling, Energy, Emissions.

\section{Introduction}

Rice, the staple food for the 150 million people of Bangladesh, contributes 58.3 percent of value added in agriculture to GDP (9.1 percent of total GDP). Rice is the main source of calories for the people of the country, accounting about 72.8 percent of calories consumed in 1998 [1]. In Bangladesh, per capita consumption of rice is $168 \mathrm{~kg} /$ year [19], which indicates that most of the people of Bangladesh are dependent on rice to fulfill their daily food requirements. Bangladesh produces a bulk amount of rice every year to mitigate the calories needed for her people. The International Rice Research Institute (IRRI) reported that the total rough rice production in the world was more than 600 million tonnes approximately in 2004 [2] and Bangladesh, the $4^{\text {th }}$ largest rice producing country, produced about $6 \%$ of the total world rice production in that year. This is an indication of abundant biomass production as rice milling by-products in Bangladesh. In 2006, the country produced about 39.59 million tonnes of paddy (rough rice) [3]. This bulk amount of rice was processed to supply the main food. There are different methods of rice processing in Bangladesh. About 30\% of the total paddy processed by households does not enter the market. Another $20 \%$ is processed in large rice mills where mechanical drying is done. The rest $50 \%$ of the total paddy is processed in small and medium rice mills where natural sunshine is used for drying.

About $90 \%$ of the rice is parboiled in Bangladesh [4]. People in Bangladesh are habituated to the taste of parboiled rice, which is claimed to have a better shelf-life than raw rice (un-parboiled) due to the gelatinization of starch [16]. Parboiled rice also gives higher milling output than raw rice. The head rice recovery was reported as $51 \%$ and $60-80 \%$ from raw rice and parboiled rice, respectively [20, 21].

Rice husk is a by-product of rice and has a good value as a biomass fuel. This biomass amounts to $20 \%$ of total rough rice (paddy) produced. Rice husk is mainly used as fuel for parboiling and drying of paddy before milling. In a study conducted in West Bengal, India, it was reported that 1,659 MJ of biomass energy was consumed for rice parboiling [7]. In a study by the IDRC (International Development Research Center, Canada) it was reported that theoretically the net energy demand for hot soaking, steaming and drying were $360 \mathrm{MJ}, 105.5 \mathrm{MJ}$ and $574 \mathrm{MJ}$, respectively, to process one tonne of paddy. It was also mentioned that about $200 \mathrm{~kg}$ of rice husk (2,800 MJ) was needed to process one tonne of paddy if the efficiency of a husk fired boiler is $45 \%$ [10].

In fact, it is a normal practice in Bangladesh that the rice is first parboiled and dried and then it is dehusked. However, it was reported that if the rice is dehusked before parboiling then the energy consumption of parboiling operation could be cut down by $40 \%$ [22]. The drying process is mainly done under direct sunlight radiation on a floor. There are some mechanical processes for paddy drying wherein the rice husk is used as a source of thermal energy for air heating and electricity is used for running blower-motors. The specific energy consumption of drying is largely dependent on the moisture content and hot air temperature.

LSU (Louisiana State University) type dryers are used for mechanical drying of rice in Bangladesh. LSU type dryers are a mixing type of dryer. They consist of a vertical compartment and the rice grain falls down from the top of the dryer and is re-circulated until it is dried. As the rice descends in the 
dryer it is mixed so that individual grains are not exposed to only the hottest air, but rather a combination of both hotter and cooler air. Because of this, the LSU type dryers generally use higher temperatures and lower air velocities than non-mixing dryers [10]. It was reported from a comparative study of rotary dryer and 3-stage counter flow dryer that use of 3-stage counter flow dryer resulted in a $34 \%$ savings in fuel energy [9]. After drying the milling process is completely done using electrical energy.

Theoretically it is assumed that about $200 \mathrm{~kg}$ of husk can be obtained from each tonne of paddy, however, in practice, it was found that on average $187 \mathrm{~kg}$ of husk could be obtained from each tonne of paddy [11]. The parboiling and drying operation of rice processing consumes a huge amount of energy from renewable sources. Specific energy consumption of rice processing is reported in several studies. However, this study also analyzed the energy demand nationally for rice processing in Bangladesh. It is high time, since as an energy-starved country, Bangladesh needs proper assessment of energy consumption for rice processing from a national perspective. The environmental issue is a great concern for the country like Bangladesh, especially for the adverse effects of sea level rise due to global warming.

It was reported that carbon dioxide emissions from rice processing varied from $938.2 \mathrm{~kg}$ to 1,360.0 $\mathrm{kg}$ for each tonne of finished rice [12]. Carbon dioxide emissions resulting from rice processing are an environmental concern leading to increased emissions of greenhouse gas. Therefore, the study was conducted to investigate the energy consumption pattern and the global warming potential of rice processing in Bangladesh.

\section{Results and Discussion}

\subsection{Energy Consumption in Different Operations of Rice Processing}

Bangladesh has been producing a significant amount of staple food grains for the last four decades as shown in Figure 1. The rice production has also increased to meet the demand of the increased population of the country and since the independence of Bangladesh in 1971, an increased rice production trend has been observed. The rice production increased from 15 million tonnes in 1972 to approximately 40 million tonnes in 2006. The growth rate of rice production was calculated to be $2.2 \%$ [3]. This bulk amount of rough rice is processed locally; both in households and at commercial levels and about 1.775 million of people are engaged in the rice processing sector [23]. Energy requirements are a great concern for processing of this bulk amount of rice.

About $70 \%$ of rice is processed in local rice mills with the rest of the amount being processed at an individual household level, which includes some grain retained as seed. In this study the energy requirement for rice processing at a commercial level was discussed. There are three different stages of paddy processing in commercial rice mills viz. i) parboiling process, ii) drying of the parboiled paddy and finally, iii) milling operation to get finished product. The different operations of the rice parboiling systems are shown in Photo 1. 
Figure 1. Production of raw rice (paddy) in Bangladesh [3].

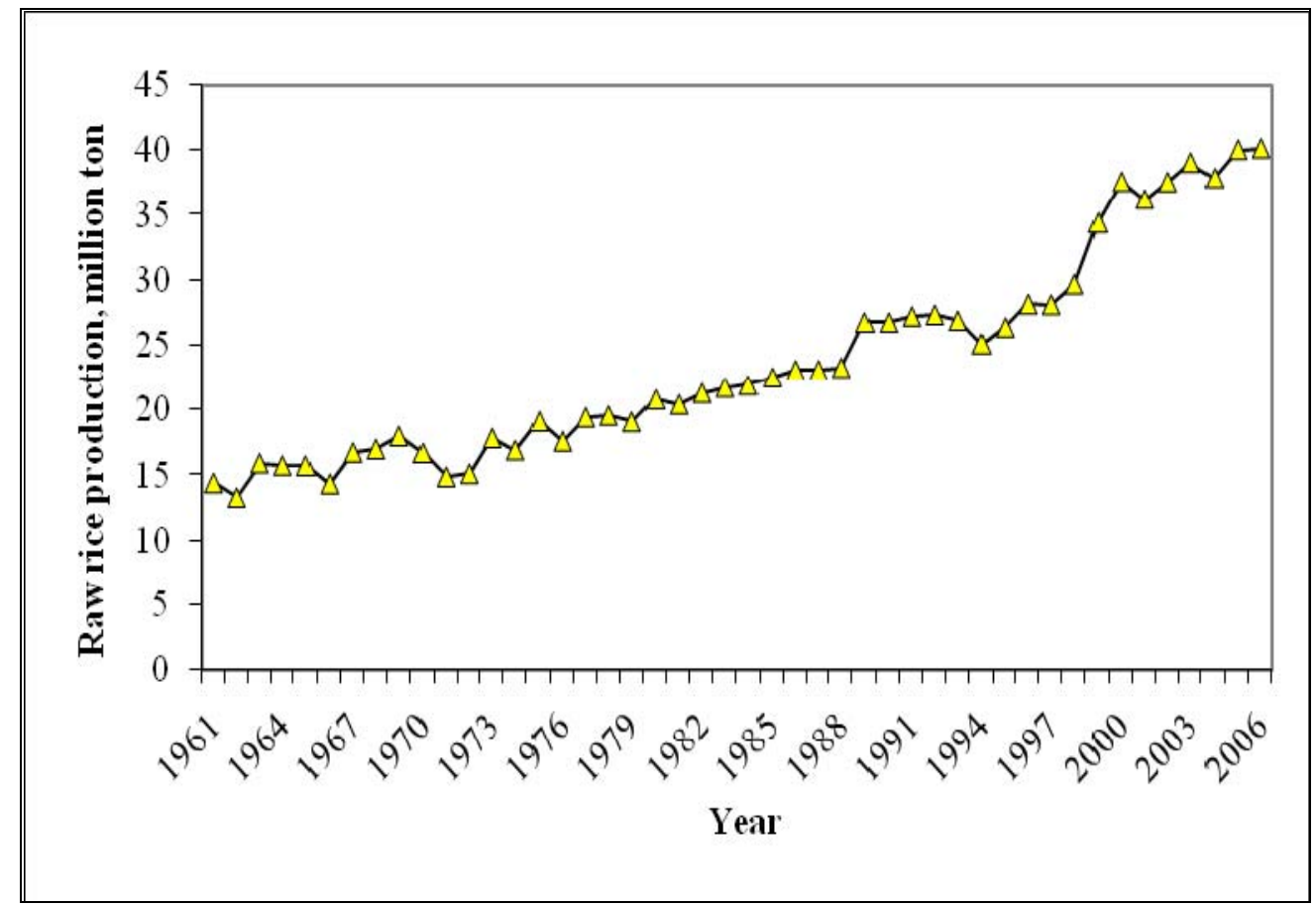

Photo 1. Showing different rice processing operations in Bangladesh.

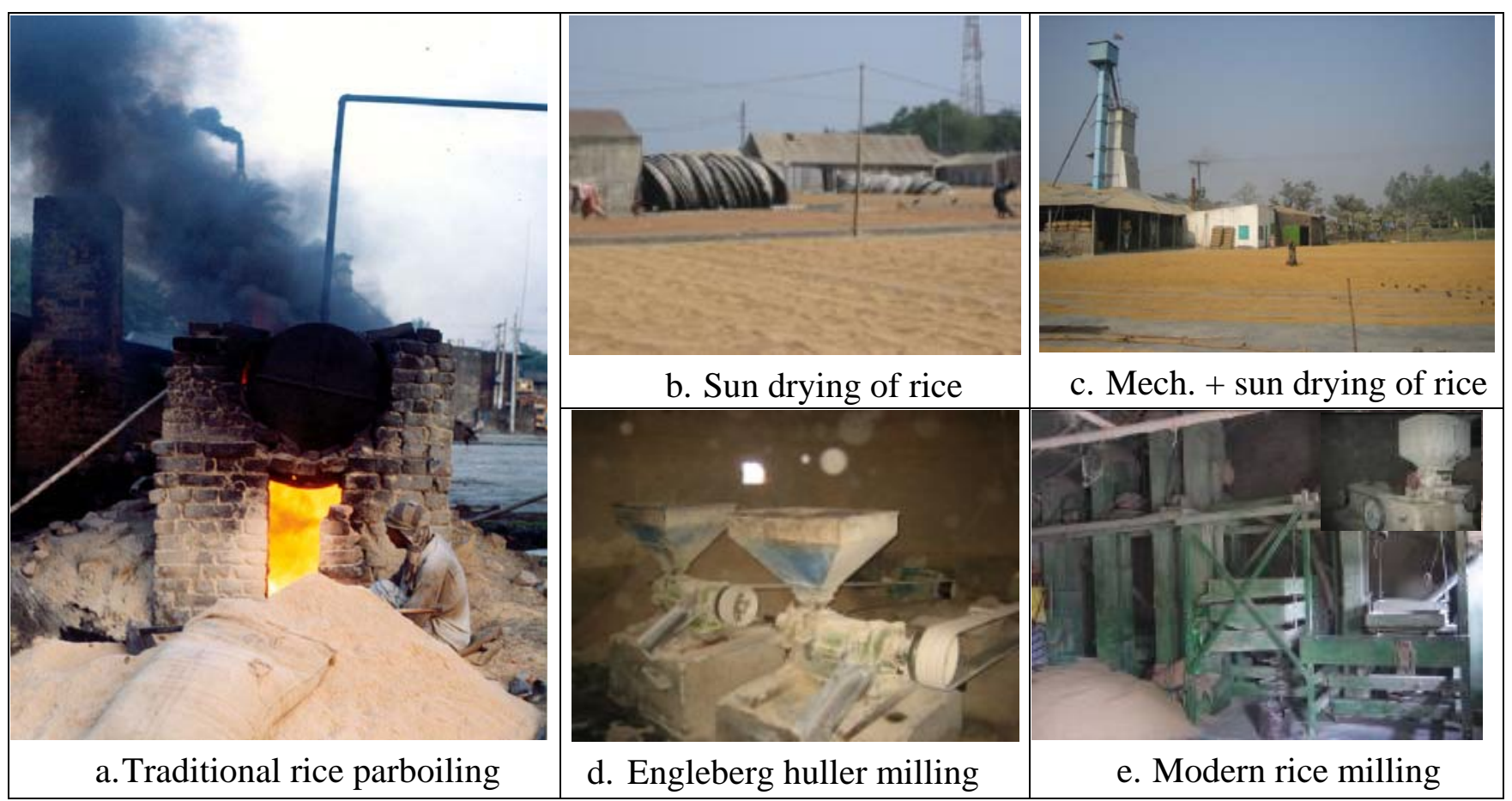

The energy intensities of different unit-operations of rice processing are shown in Table 1 . The energy intensity for different operations depends on the type of technology used and the energy efficiency of the technology. The thermal energy efficiency of rice parboiling system used in Bangladesh is very low (15-30\%). The theoretical demand of thermal energy for parboiling is variously reported from $241 \mathrm{MJ} /$ tonne to $460 \mathrm{MJ} /$ tonne [10,13] of paddy, whereas the actual consumption of thermal energy for parboiling was found to be $1680 \mathrm{MJ} /$ tonne (Table 1) and similar 
results was also reported as $1,659 \mathrm{MJ} /$ tonne [7]. There is obviously a great potential to increase the thermal efficiency of rice parboiling system in Bangladesh.

Table 1. Energy intensity of different unit-operation of rice processing.

\begin{tabular}{|c|c|c|c|}
\hline Activity level & $\begin{array}{c}\text { Rice husk energy } \\
\text { (kg/tonne) }\end{array}$ & $\begin{array}{c}\text { Solar } \\
\text { (MJ/tonne) }\end{array}$ & $\begin{array}{c}\text { Electricity } \\
\text { (kWh/tonne) }\end{array}$ \\
\hline Parboiling & $\begin{array}{c}120 \\
(1,680 \mathrm{MJ} / \text { tonne })\end{array}$ & - & - \\
\hline Sun Drying & - & $556^{*}$ & - \\
\hline Sun + Mechanical drying & $\begin{array}{c}70^{* *} \\
\text { (980 MJ/tonne) }\end{array}$ & $340^{*}$ & $\begin{array}{c}8.7 \\
\text { (31.32 MJe/tonne) }\end{array}$ \\
\hline Mechanical drying & $\begin{array}{c}110^{* *} \\
(1,540 \mathrm{MJ} / \text { tonne })\end{array}$ & - & $\begin{array}{c}17.4 \\
\text { (62.64 MJe/tonne) }\end{array}$ \\
\hline Steel huller milling (Engleberg) & - & - & $\begin{array}{c}19.0 \\
\text { (68.40 MJe/tonne) }\end{array}$ \\
\hline Modern milling & - & - & $\begin{array}{c}29.26 \\
\text { (105.33 MJe/tonne) }\end{array}$ \\
\hline
\end{tabular}

Source: Field survey 2008, Calorific value of rice husk = $14 \mathrm{MJ} / \mathrm{kg}$ [5], $1 \mathrm{kWh}=3.6 \mathrm{MJ}$;

${ }^{*}$ Indicates the energy needed to evaporate water only; ${ }^{* *}$ Indicates actual energy consumed (initial moisture level 32\% and final moisture level 14\%)

The paddy is dried to a safe level of moisture (14\%) before milling. The energy needed for drying of parboiled paddy comes from two sources. The major portion of parboiled rice is dried under direct sunlight. The solar energy needed for drying was calculated as latent heat of water evaporated from the moist paddy. The mechanical drying needs both the thermal and mechanical energy. The thermal energy comes from rice husk and the need of mechanical energy is satisfied with electrical energy. The primary energy consumption for mechanical drying was found to be 1,540 $\mathrm{MJ} /$ tonne of paddy dried to reduce moisture level from $32 \%$ to $14 \%$ under a hot air temperature range of $65-130^{\circ} \mathrm{C}$. The specific energy consumption was $6.25 \mathrm{MJ} / \mathrm{kg}$ of water evaporated from the grain. It was reported that the specific energy consumption for paddy drying operating within air temperature $50-200^{\circ} \mathrm{C}$ was $4-10$ $\mathrm{MJ} / \mathrm{kg}$ of water evaporated [24] and within air temperature $103-149^{\circ} \mathrm{C} 2-8 \mathrm{MJ} / \mathrm{kg}$ of water evaporated [25]. A combination of sun and mechanical drying was also observed during the study. In this process, the free water from moist paddy is dried under sunshine during the daytime and then the paddy is dried in a mechanical dryer (LSU type) during the evening. The electrical energy for mechanical drying was found to be $17.4 \mathrm{kWh} /$ tonne. It was reported that electrical energy required for mechanical drying varied from $9.30 \mathrm{kWh} /$ tonne to $30.46 \mathrm{kWh} /$ tonne [13]. The electrical energy consumption was found to be $8.7 \mathrm{kWh} /$ tonne for the combination of sun and mechanical drying system, indicating an energy saving option for drying operations.

The milling operation is completely done by the mechanical energy and this demand is satisfied with grid electricity. There are two types of milling machinery, viz. steel huller (Engleberg) type and modern milling (combination of rubber roll sheller and polisher). The milling machinery needs higher 
electrical load for its several operation viz. pre-cleaning, shelling, separation, grading, polishing, etc. The electrical energy consumption was found to be $29.26 \mathrm{kWh} /$ tonne of paddy processed by a 2 tonne per hour capacity modern mill. It was reported that electrical energy consumption was 29.84 $\mathrm{kWh} /$ tonne for a 2 tonne per hour capacity modern mill and $28.46 \mathrm{kWh} /$ tonne for a 4 tonne per hour capacity modern rice mill [13]. In the Engleberg huller type rice mill no pre-cleaning, shelling, grading systems were found. In this milling system, paddy is shelled, milled and separated simultaneously in the huller with a rotating steel shaft. The energy consumption for the Engleberg huller system was found to be $19.0 \mathrm{kWh} /$ tonne.

Electrical energy consumption is a great concern for Bangladesh as an energy-starving country. The load of electrical energy varied according to the capacity of rice mill. The Engleberg huller milling systems need only one electric motor to run the mill, whereas the modern rice mills need several electric motors for different functions such as cleaning, dehulling, separation, conveyor, polishing, grading etc. In this study, the average load of electrical energy was found to be $30.4 \mathrm{~kW}$ for steel huller (Engleberg) type and $150.6 \mathrm{~kW}$ for modern milling systems. Total electrical load for rice processing depends on the number of rice mills operated in the country. There is no actual statistics available for the number of rice mill in Bangladesh. However, Ministry of Food maintains a list of rice mills to collect finished rice for buffer stock of food for the country. For this the Directorate General of Food enlisted about 25,000 of small rice mill and 500 large rice mills throughout the country [14]. Based on this number of rice mill the total peak load of the rice mill was estimated as $835.3 \mathrm{MW}$ (Table 2).

Table 2. Electrical load of rice mill.

\begin{tabular}{lccc}
\hline Activity & $\begin{array}{c}\text { Average load } \\
(\mathbf{k W})\end{array}$ & $\begin{array}{c}\text { No. of rice } \\
\text { mills** }\end{array}$ & $\begin{array}{c}\text { Total peak load } \\
\text { (MW) }\end{array}$ \\
\hline Steel Huller Mill (Engleberg) & 30.4 & 25,000 & 760.0 \\
Modern rubber roll mill & 150.6 & 500 & 75.3 \\
Total peak load & \multicolumn{2}{c}{835.3} \\
\hline
\end{tabular}

*Field survey 2008, **Directorate General of Food 2005 [14]

Total energy demand for rice processing primarily depends on the quantity of rice to be processed, which in turn depends on the rice production in the country. The demand for rice is constantly increasing in Bangladesh, with nearly 2.3 million people being added each year to its population [30]. According to the Bangladesh census results, the population growth rates were $2.88 \%$ in $1981,1.58 \%$ in 2001 [31] and 2.02\% (estimated) in 2008 [32]. Though the population growth rate decreased in recent decades, it is not expected to stabilize within the next 25-30 years. Therefore, Bangladesh must continue to expand rice production by enhancing yields at least at a rate equal to the population growth rate until the demand for rice has stabilized. In addition, there are several production constraints in Bangladesh such as droughts, lack of irrigation facilities, flooding and salinity of soils etc. [30]. It is noted that UNDP has identified Bangladesh to be the most vulnerable country in the world to tropical cyclones and the sixth most vulnerable country to floods [26]. 
Despite the fact that there were severe floods and cyclones in Bangladesh in 1984, 1987, 1988, 1998, 2004 and 2007 [27,28,29], the required production of rice was achieved satisfactorily with a stable growth rate of rice production (Figure 1). The production growth rate of rice was $2.2 \%$ during 1961 to 2006. Therefore, to predict the future rice production, the present growth rate of rice production was considered in this study. A projected rice production from 2000 to 2030 is shown in Figure 2. To satisfy this demand about 60 million tonnes of rough rice is required to be produced by 2030 which leads to increased demand of energy for rice processing and also the increased emission to the environment.

Figure 2. Trends of projected rough rice production in Bangladesh by 2030.

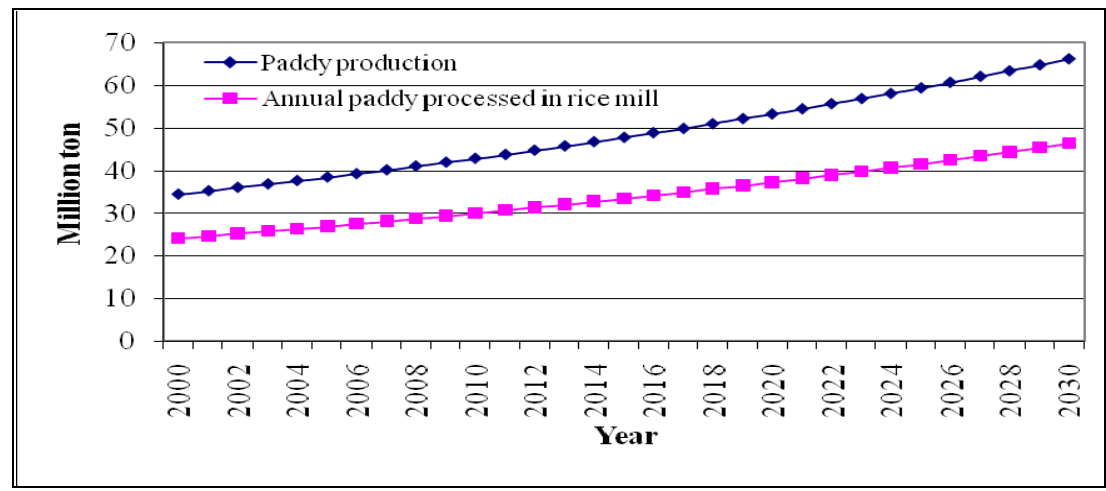

The final energy demand in future for rice processing in Bangladesh was estimated based on the energy intensity of different operation of rice processing according to the increased production of rough rice. The energy demand in future for rice processing and the potential global emission from rice processing activities was analyzed by using energy planning and mitigation software 'Long-range Energy Alternatives Planning System' (LEAP). This software can be downloaded from Internet. The users from developing countries can have free license by registering online. LEAP represents a relatively easy to use and flexible accounting and modeling framework developed by the Stockholm Environment Institute [6].

Table 3. Final energy demand for rice food grain process.

\begin{tabular}{|c|c|c|c|}
\hline Unit operation \\
Year & 2000 & 2010 & 2030 \\
\hline \multicolumn{4}{|l|}{ Parboiling operation } \\
\hline Rice Husk (Million GJ) & 40.5 & 50.3 & 77.8 \\
\hline \multicolumn{4}{|l|}{ Drying operation } \\
\hline Rice Husk (Million GJ) & 7.7 & 9.5 & 14.7 \\
\hline Electricity (Million GJ) & 0.3 & 0.4 & 0.6 \\
\hline Solar (Million GJ) & 10.7 & 13.3 & 20.5 \\
\hline \multicolumn{4}{|l|}{ Milling operation } \\
\hline Electricity (Million GJ) & 1.83 & 2.27 & 3.51 \\
\hline
\end{tabular}

Calorific value of rice husk $=14 \mathrm{MJ} / \mathrm{kg}[5], 1 \mathrm{kWh}=3.6 \mathrm{MJ}$ 
LEAP is a scenario-based energy-environment modeling tool. Its scenarios are based on comprehensive accounting of how energy is consumed, converted and produced in a given region or economy under a range of alternative assumptions on population, economic development, technology, price and so on. A scenario for final energy demand in future for rice processing was analyzed by using LEAP software and Table 3 and Figure 3 show the scenario results. In parboiling operations, the paddy is boiled partially with steam. The steam is produced in a boiler by combusting the rice husk. The consumption of rice husk energy for parboiling of paddy is estimated as 40.5 million GJ in 2000 which will increase to 77.8 million GJ in 2030 (Table 3).

Figure 3. Final energy demand for rice food grain processing in Bangladesh.

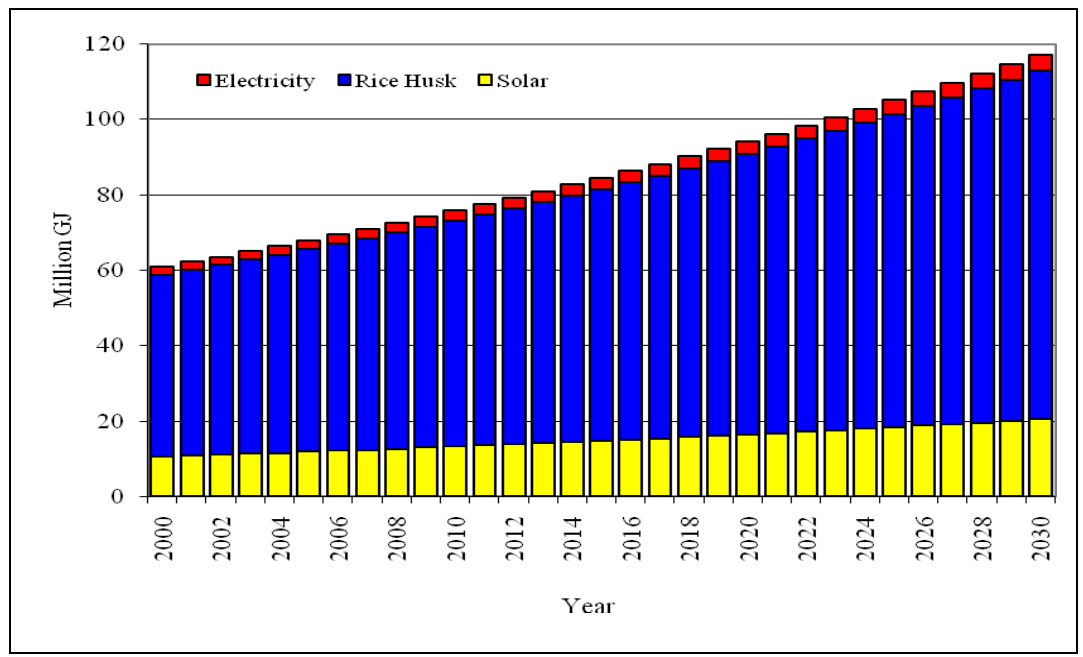

In drying operations, the moisture in the paddy grain is removed by applying heat energy. The drying operation is done in three different ways viz. i) direct radiation of sunlight, ii) mechanical drying, and iii) the combination of sun drying and mechanical drying. In the mechanical drying method, rice husk energy is used as a source of thermal energy and electrical energy is used to blow the hot air through the wet grain. The consumption of rice husk, electricity and solar energy for drying were 7.7 million GJ, 0.3 million GJ and 10.7 million GJ, respectively in the year 2000 and those values will increase to 14.7, 0.6 and 20.5 million GJ, respectively in 2030 (Table 3).

The final stage of rice processing is the milling operation. In this operation, the dried paddy is processed to separate the food grain. In this stage only the electrical energy is used to run the milling machinery. The consumption of electrical energy in milling operation is estimated as 1.83 million GJe in the year 2000 and 3.51 million GJ $\mathrm{e}_{\mathrm{e}} 2030$ (Table 3).

The above discussion clearly indicates that major energy for rice processing comes from renewable energy sources such as biomass and solar. The largest amount of primary energy came from rice husk. The second highest amount of primary energy is consumed from sun light in drying operation. The electrical energy is required in mechanical drying and milling operation. The consumption pattern of different type of energy for rice processing system is shown in Figure 3. A large quantity of rice husk is consumed for rice processing. The total rice husk consumption was estimated as 48.2 million GJ (3.44 million tonnes) in 2000. 
There are several options to reduce the energy consumption. The most promising option is to increase the efficiency of rice parboiling systems. The efficiency of existing rice parboiling systems is very low (15-30\%). The boiler efficiency can easily be increased to $50 \%$. Then about $50 \%$ of the rice husk (1.72 million tonnes in 2000) could be saved and this bulk amount of rice husk can easily be briquetted and could be used as replacement of wood fuel. This rice husk could even be used for electricity generation. The other option is to discontinue the parboiling process. If the raw rice is processed then most of the rice husk can be saved by stopping the parboiling process. But there are some limitations to stop the parboiling process. One of the limitations is that for ages most of the people of Bangladesh are already habituated to the taste of parboiled rice. People do not like the raw rice for their meal on the table. The other limitation is the penalties in nutrition and in milling output if the rice is not parboiled. Parboiling results in an inward diffusion of water soluble B vitamins (thiamine, riboflavin and niacin) which causes vitamin enrichment in the grain. However, thiamine is partially degraded during heat treatment while riboflavin content remains the same in parboiling. Despite the degradation of thiamine, parboiled milled rice contains higher vitamins than raw milled rice [15-18]. Since rice is the major source of calories for the people of Bangladesh therefore, parboiled rice can contribute significantly to supplement their nutritional intake.

Dehulling of rice before parboiling process is also a possible option to reduce energy consumption for rice parboiling [8]. The process of parboiling of dehusked rice could save about $40 \%$ energy and could be easily adopted by primary processors in developing countries. The rice have been organoleptically evaluated and found acceptable [22]. However, this type of process is susceptible to contamination if the processing equipment is not as per food grade quality and it needs shade drying instead of open floor drying under sunshine as in traditional practices.

Energy consumption could be reduced by improving the mechanical drying system. The hot fluegas obtained on combustion of rice husk from parboiling system is exhausted to air. This fluegas could be used to make hot air for drying. If this hot air could be supplied to dryer then the primary energy demand for mechanical drying would be less.

\subsection{Global Warming Potential}

The potential environmental impact of rice processing in Bangladesh was analyzed with the LEAP software [6]. The global warming potential $\mathrm{CO}_{2}$ equivalent is shown in Figure 4. Since the most energy required for rice processing comes from renewable sources, the global warming potential is very less. Both the biogenic and non-biogenic $\mathrm{CO}_{2}$ emission was calculated. The total $\mathrm{CO}_{2}$ emission of rice processing in Bangladesh was estimated to be 6.1 million tonnes in 2000 and this value will increase to 11.7 million in 2030. Out of the total emissions, the biogenic $\mathrm{CO}_{2}$ emission was estimated as 5.7 million tonnes in 2000 and this value will increase to 10.9 million tonnes in 2030 . The biogenic carbon dioxide emission occurred due to the burning of rice husk and this mass of $\mathrm{CO}_{2}$ is renewed by rice plants every year. The net $\mathrm{CO}_{2}$ emission of rice processing from the non-biogenic carbon dioxide was estimated to be 0.4 million tonnes in 2000 and this value will increase to 0.7 million tonnes in 2030 (Figure 2). 
Figure 4. Global warming potential due to rice processing in Bangladesh.

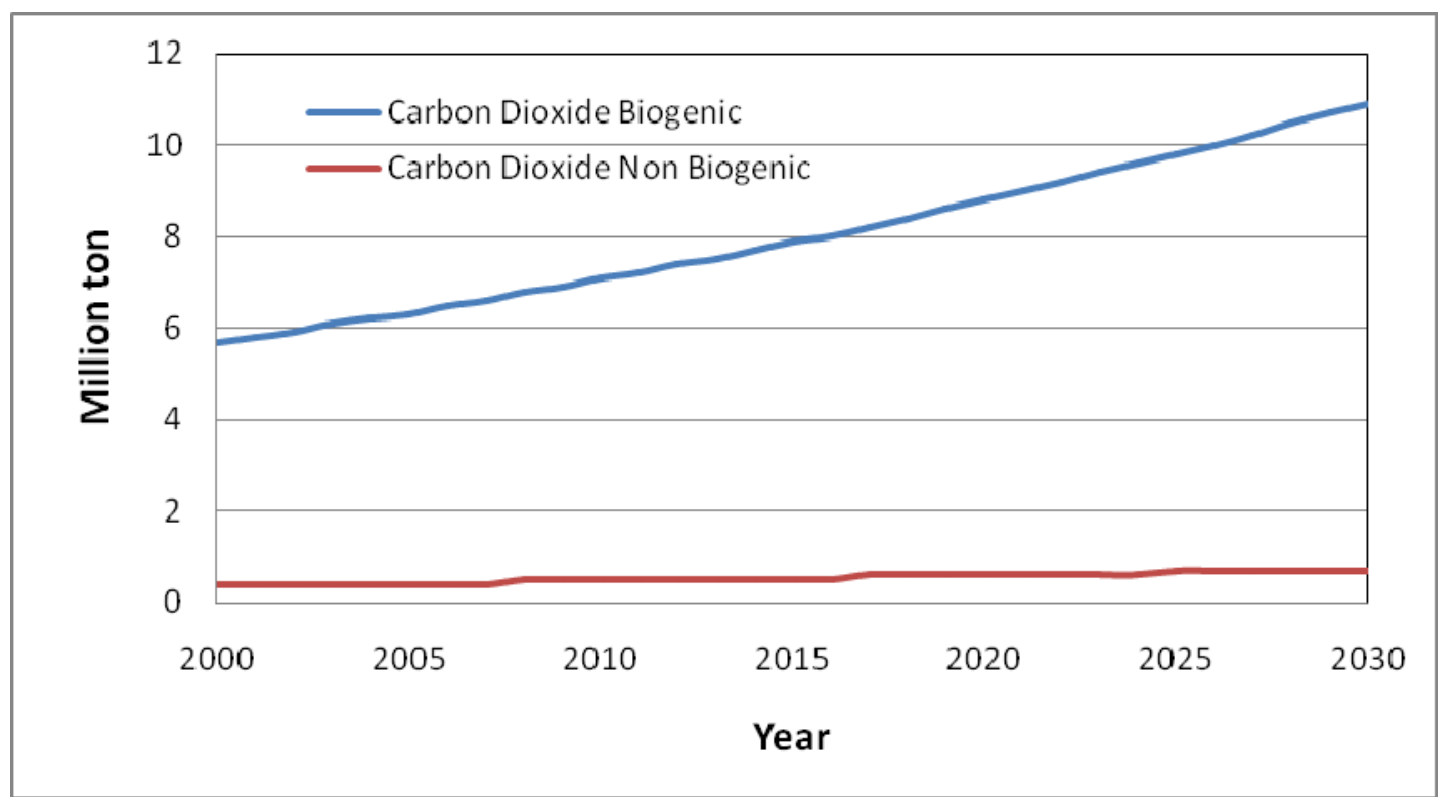

The non-biogenic carbon dioxide emissions occur due to the electrical energy use. The biogenic $\mathrm{CO}_{2}$ emission could easily be reduced by increasing the efficiency of rice parboiling boiler. The increased efficiency of rice parboiling boiler could enable availability of rice husk. This husk could save $\mathrm{CO}_{2}$ by replacing fuel wood if the husk is briquetted. Even this husk could reduce non-biogenic $\mathrm{CO}_{2}$ emission (the net $\mathrm{CO}_{2}$ emission from fossil fuel for electricity) if the husk would be used for electricity generation. There is another option of saving $\mathrm{CO}_{2}$ from mechanical dryer. Proper design of heat exchanger and proper rated design of blower for hot air circulation might help to reduce energy consumption. It is evident that $\mathrm{CO}_{2}$ emissions can be significantly decreased due to the potential strategies of rice processing in Bangladesh. It could be added that the Government of Bangladesh and donors have pledged to create a fund known as the Climate Change Fund for a country like Bangladesh already threatened by global warming and sea level rise. Therefore, necessary grant for the development of rice processing in Bangladesh can be obtained from the 'climate change' and 'clean development mechanism’ fund.

\section{Materials and Methods}

This study was conducted in major rice mill clusters (viz. Dinajpur, Naogaon, Bogra and Ishawrdi) of the northern part of Bangladesh. There are hundreds of rice mills in each cluster. An aerial view of a large rice mill cluster at Pulhat, Dinajpur district of Bangladesh is shown in Map 1. The drying floor of rice mills are shown as white spots in the yellow border area in the Map 1. The golden color of the drying floor having the presence of the raw paddy on the drying floor.

The different unit operations of rice food grain processing were critically analyzed to determine the energy consumption from different sources. Mainly there are three different unit operation of rice food processing, viz. i) parboiling, ii) drying and iii) milling. Out of these three unit-processes parboiling and drying need thermal energy. 
Map 1. Aerial view of rice mill cluster at Pulhat, Dinajpur district of Bangladesh.

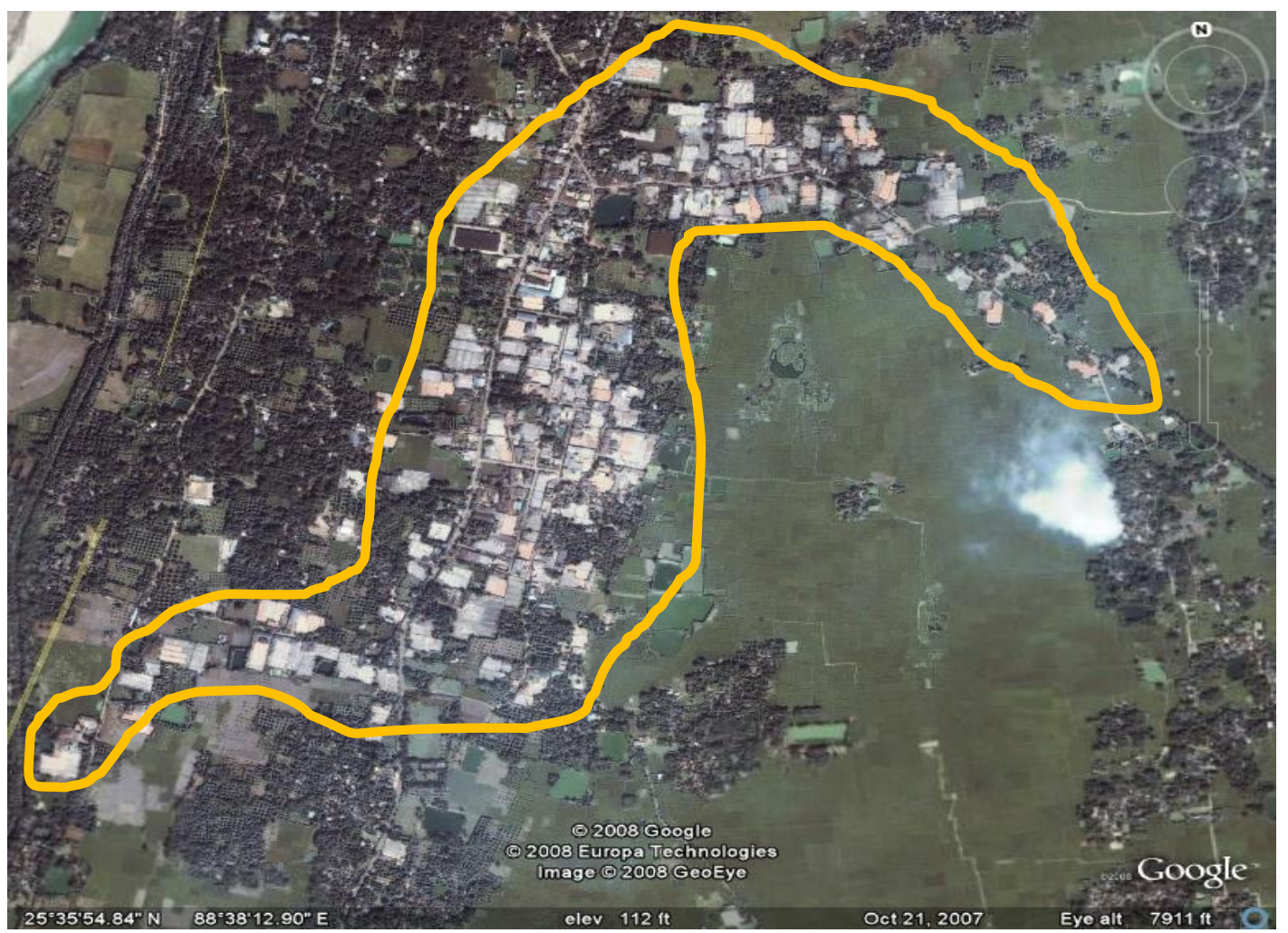

(This picture was taken from Google Earth software, printed on 30.11.08)

The parboiling process is the partial boiling of rough rice (paddy) with steam. The parboiling process requires energy from steam and this is produced by using rice husk. The quantity of the husk fed to the furnace for parboiling purposes was measured directly by a weighing balance. The quantity of the paddy parboiled in a batch was recorded from the register of the rice mill. Then the energy required for parboiling of paddy is calculated using Equation (1):

$$
E_{\text {parboil }}=\frac{W_{\text {husk }} \times C_{\text {husk }}}{W_{\text {paddy }}}-----(1)
$$

Where:

$\mathrm{E}_{\text {parboil }}=$ energy required for parboiling of paddy, $\mathrm{kJ} /$ tonne

$\mathrm{W}_{\text {husk }}=$ weight of husk required for parboiling, $\mathrm{kg}$

$\mathrm{W}_{\text {paddy }}=$ weight of paddy parboiled, tonne

$\mathrm{C}_{\text {husk }}=$ calorific value of rice husk, $\mathrm{kJ} / \mathrm{kg}$

After parboiling the paddy is left to dry. Drying is the removal of moisture from parboiled paddy. The drying operation is mainly done on a floor under direct sunlight radiation. The drying process requires a huge amount of thermal energy for removing the moisture from paddy. The moisture content of the parboiled paddy was determined by digital moisture meter at field level as well as by oven dry method. The initial moisture content after parboiling was 32\% and after drying the moisture content was $14 \%$. To calculate the water removed from rough rice during drying process, the following Equation (2) is used. The thermal energy requirement for the sun drying of paddy is calculated using Equation (3): 


$$
W_{w}=\frac{M_{w}}{1-M_{w}} \times W_{d}-------(2)
$$

where:

$\mathrm{W}_{\mathrm{w}}=$ water removed from paddy, $\mathrm{kg}$

$\mathrm{M}_{\mathrm{w}}=$ moisture content in paddy, decimal

$\mathrm{W}_{\mathrm{d}}=$ weight of dry mass of paddy, kg

$$
E_{\text {sun_drying }}=W_{w} \times L---------(3)
$$

where:

$\mathrm{E}_{\text {sun_drying }}=$ energy required for sun drying, $\mathrm{kJ}$

$\mathrm{W}_{\mathrm{w}}=$ water removed from paddy, $\mathrm{kg}$

$\mathrm{L}=$ latent heat of evaporation of water, $\mathrm{kJ} / \mathrm{kg}$

The energy required for mechanical drying comes from two sources viz. heat energy from rice husk combustion and electrical energy from grid for blowing hot air. The quantity of husk required for drying purposes was weighed by a balance. The quantity of electrical energy consumed for drying was recorded from the energy meter. The quantity of energy required for mechanical drying are calculated as follows Equation (4) \& Equation (5):

$$
E_{\text {heat_drying }}=\frac{W_{\text {husk }} \times C_{\text {husk }}}{W_{\text {paddy }}}-----(4)
$$

where:

$E_{\text {heat_drying }}=$ heat energy required for mechanical drying of paddy, $\mathrm{kJ} /$ tonne

$\mathrm{W}_{\text {husk }}=$ weight of husk required for mechanical drying, $\mathrm{kg}$

$\mathrm{W}_{\text {paddy }}=$ weight of paddy dried, tonne

$\mathrm{C}_{\text {husk }}=$ calorific value of rice husk, $\mathrm{kJ} / \mathrm{kg}$

$$
E_{\text {elec_drying }}=\frac{E_{k W h}}{W_{\text {paddy }}}---------(5)
$$

where:

$E_{\text {elec_drying }}=$ energy required for mechanical drying, $\mathrm{kWh} /$ tonne

$\mathrm{E}_{\mathrm{kWh}}=$ electricity consumed during mechanical drying operation, $\mathrm{kWh}$

$\mathrm{W}_{\text {paddy }}=$ weight of paddy dried, tone

After drying the paddy is milled to get rice food grain. Rice husk is obtained as a by-product of milling that is ready for using as energy for parboiling. Electrical energy from the national grid is used for milling of paddy. The quantity of electrical energy was calculated from the energy meter reading and the monthly electricity bill. The electricity needed for milling of paddy is measured as following Equation (6):

$$
E_{\text {milling }}=\frac{E_{k W h}}{W_{\text {paddy }}}
$$

where:

$\mathrm{E}_{\text {milling }}=$ energy required for milling, $\mathrm{kWh} /$ tonne 
$\mathrm{E}_{\mathrm{kWh}}=$ electricity consumed during milling operation, $\mathrm{kWh}$

$\mathrm{W}_{\text {paddy }}=$ weight of paddy milled, tonne

The energy demand in rice processing in the future and the potential global emissions from rice processing activities were analyzed by using energy planning and mitigation software 'Long-range Energy Alternatives Planning System' (LEAP). This software was downloaded from the Internet. It provides a free license for users from developing countries. A scenario was analyzed using LEAP software to see the energy consumption pattern and to determine the global warming potential from rice processing in Bangladesh. Energy demand is calculated as following Equation (7):

$$
E_{\text {demand }}=\sum A \times E I
$$

where:

$\mathrm{E}_{\text {demand }}=$ energy demand, $\mathrm{GJ}$

$\mathrm{A}=$ activity level, tonne paddy processed

$\mathrm{EI}=$ energy intensity for the activity, GJ/tonne

To address the emissions, LEAP includes a Technology and Environmental Database (TED) that provides extensive information describing the technical characteristics and environmental impacts of a wide range of energy technologies, including existing technologies, current best practices and next generation devices. To calculate the $\mathrm{CO}_{2}$ emission, chemical composition of rice husk and the intensity of husk consumption were provided into the LEAP software before running the scenario. To calculate the emission from electricity generation, the type of power plant such as Hydro, Gas turbine, CC gas turbine, thermal power plant in context of Bangladesh were considered in LEAP program. The rated capacity of different power plant as of Bangladesh was directed in LEAP program. The power generation plants were assessed based on their performance and the $220 \mathrm{MW}$ Hydro power plant was found to be the most efficient one. The mathematical expression of the emission that references the chemical composition of the fuel is given by the following Equation (8):

$$
\text { Loading }_{\mathrm{CO}_{2}}=\mathrm{C}_{\text {content }} * \mathrm{FO} * \frac{\mathrm{CO}_{2}}{\mathrm{C}}
$$

where:

Loading $_{\mathrm{CO} 2}=$ carbon dioxide emission, $\mathrm{kg}$

$\mathrm{C}_{\text {content }}=$ carbon content in specified fuel, $\mathrm{kg}$

$\mathrm{FO}=$ fraction oxidized

$\mathrm{CO}_{2}, \mathrm{C}=$ constant

The emissions are calculated by the LEAP program based on the following Equation (9):

$$
\text { Emission }=E_{\text {consumption }} * E_{f}
$$

where:

$\mathrm{E}_{\text {consumption }}=$ energy consumption

$\mathrm{E}_{\mathrm{f}}=$ emission factor 


\section{Conclusions}

A huge amount of renewable energy is used for the processing of staple food rice for the 150 million people of Bangladesh each year. This study clearly indicated that Bangladesh contributes a lot to saving the earth from global warming by using a huge amount of renewable energy (3.44 million tonnes of rice husk in 2000) instead of fossil fuels in rice processing. The amount of biogenic carbon dioxide emission (6.1 million tonnes) is renewed by the rice plant every year. The non-biogenic carbon dioxide emission accounted due to the use of electrical energy from national grid. Demand of energy for rice processing is increasing every year due to the increased production of rice for ensuring food security of the population. Since Bangladesh is an energy starved country, a proper policy should be undertaken for energy conservation in the rice processing industries in Bangladesh. More energy efficient rice parboiling boilers should be introduced immediately to replace the existing inefficient rice parboiling systems. The use of efficient rice parboiling systems could make rice husks available for other sectors. If this husk could be briquetted, then it would be an alternative fuel for replacing wood-fuel. Rice husk based co-generation system could be an alternative for large rice mills, or even for a cluster of small to medium rice mills. If the electricity were generated from rice husk then net carbon dioxide emissions could be reduced.

\section{References}

1. Ninno, C. D.; Dorosh, P.A.; Smith, L.C. Public policy, markets and household coping strategies in Bangladesh: Avoiding a food security crisis following the 1998 flood, 2003. Available online: http://ideas.repec.org/a/eee/wdevel/v31y2003i7p1221-1238.html.

2. FAOSTAT. World rice production data base. 2005; pp. 1-6. Available online: http://www.irri.org/science/ricestat/pdfs/ WRS2005-Table01.pdf,

3. BBS. Statistical pocket book of Bangladesh, Bangladesh Bureau of statistics. Planning division, ministry of planning. government of the People's Republic of Bangladesh: Dhaka. 2006.

4. Dasgupta, N. Socio-economic aspects of small-scale rice milling. Benefits from improved rice husk combustion efficiency, DFID project: R7659. Natural Resources Institute, The University of Greenwich: Greenwich, UK, 2001.

5. Quaak, M.; Knoef, H.; Stassen, H. Energy from biomass: a review of combustion and gasification technology (World Bank Technical Report); Work Bank Pubilications: Washington DC., USA, 1999; No. 422, p. 5.

6. Long-range Energy Alternatives Planning System (LEAP). Stockholm Environment Institute: Boston, MA, USA, 2008. Available online: www.sei.se, www.sei-us.org.

7. Roy, P.; Shimizu, N.; Shiina, T.; Kimura, T. Energy consumption and cost analysis of local parboiling processes. J. Food Eng. 2006, 76, 646-655.

8. Amarjit, S.; Bakshi, R.; Paul, S. Kinetics of water wiffusion and starch gelatinization during rice parboiling. J. Food Sci. 2006, 45, 1387-1392.

9. Bakker-Arkema, F.W.; Fontana, C.; Kalchik, S.J.; Westelaken, C.M. Drying in commercial rice parboiling plants. CAB Abs. 1983/1984, 2, 423-433. 
10. Araullo, E.V.; de Padua, D.B.; Graham, M. RICE postharvest technology; IDRC-053e. International Development Research Centre: Ottawa, Canada, 1985, pp.198-200.

11. Ahiduzzaman, M. Rice husk energy technologies in Bangladesh. Agric. Eng. Int. CIGR E-J. 2007, 9, 4.

12. Roy, P.; Shimizu, N.; Shiina, T.; Kimura, T. Life-cycle inventory analysis of local parboiling processes, 2008. Available online: http://www.irri.org/publications/wrrc/wrrcPDF/session1008.pdf (accessed on 30.11.08).

13. Kapur, T.; Kandpal, T.C.; Garg, H.P. Rice processing in india: a generalized framework for energy demand estimation. Int. J. Energy Res. 1997, 21, 309-325.

14. Register of list of rice mill owners. Directorate General of Food, Ministry of Food and Disaster Management, Govt. of Bangladesh: Dhaka. 2005.

15. Padua, A.B.; Juliano, B.O. Effect of parboiling on thiamnin, protein and fat of rice. J. Sci. Food Agric. 1974, 25, 697-701.

16. FAO. Rice in human nutrition. FAO Food and Nutrition Series 26, 1993. Available online: http://www.fao.org/docrep/t0567e/T0567E0h.htm (accessed on 30/11/2008).

17. Grewal, P.; Sangha, J.K. Effect of processing on thiamin and riboflavin contents of some highyielding rice varieties of Punjab. J. Sci. Food Agric. 1990, 52, 387-391.

18. Kik, M.C.; Williams, R.R. The nutritional improvement of white rice; Nat. Acad. Sci. Bull. National Research Council: Washington, D.C., 1945; volume 112.

19. FAOSTAT. Food and agriculture organization of the United Nations, FAO statistical database; Rome: Italy, 2001. Available online: http://apps.fao.org/.

20. Ahiduzzaman, M. Survey of major rice mill clusters of Rajshahi division: a survey report submitted to GTZ. German Technical Cooperation: Dhaka, Bangladesh, May 2008.

21. Sareepuang, K.; Siriamornpun, S.; Wiset, L.; Meeso, N. Effect of soaking temperature on physical, chemical and cooking properties of parboiled fragrant rice. World J. Agric Sci. 2008, 4 (4), 409-415; Available online: http://www.idosi.org/wjas/wjas4(4)/1.pdf

22. Kar, N.; Jain, R.K.; Srivastav, P.P. Parboiling of dehusked rice. J. Food Eng. 1999, 39, 17-22.

23. Fakhrul Islam, S.M, Bangabandhu Sheikh Mujibur Rahman Agricultural University: Gazipur, Bangladesh. Personal communication on 30 June 2008.

24. Srzednicki, G.; Driscoll, R.H. Implementation of a two-stage drying system for grain in Asia. Food Science and Technology Group, School of Chemical Sciences and Engineering, The University of New South Wales: Sydney, Australia; International Union of Food Science and Technology: Oakville, Ontario, Toronto, Canada, 2008; Chapter 7, p. 5. (E-mail: g.srzednicki@unsw.edu.au.)

25. Meeso, N.; Soponronnarit, S.; Wetchacama, S. Evaluation of drying system performance in rice mills. quality assurance in agricultural produce. In ACIAR Proceedings 100, Australia, 2000; pp. 286-291.

26. A global report: reducing disaster risk: a challenge for development; UNDP: New York, USA, Available online: http://www.undp.org/bcpr.

27. National adaptation programme of action; Ministry of Environment and Forests: Dhaka, Bangladesh, 2005. 
28. Consolidated damage and loss assessment, lesson learnt from the flood 2007 and future action plan; Disaster Management Bureau: Dhaka, Bangladesh, 2007.

29. Bangladesh climate change strategy and action plan 2008; Ministry of Environment and Forests: Dhaka, Bangladesh, Sept. 2008.

30. Bangladesh: Rice is life. Available online: http://www.worldbank.org/html/cgiar/ newsletter/june97/9bang.html (accessed on 16.02.2006).

31. Bangladesh census results at a glance. Available online: http://www.bbs.gov.bd/dataindex/ census/bang_atg.pdf (accessed on 01.03.2009).

32. The World Factbook. Available online: https://www.cia.gov/library/publications/the-worldfactbook/print/bg.html (accessed on 01.03.2009).

(C) 2009 by the authors; licensee Molecular Diversity Preservation International, Basel, Switzerland. This article is an open-access article distributed under the terms and conditions of the Creative Commons Attribution license (http://creativecommons.org/licenses/by/3.0/). 